\title{
Love, Narratives, Politics: \\ Encounters between \\ Hannah Arendt and Rosa Luxemburg
}

\author{
Maria Tamboukou
}

University of East London, UK

\begin{abstract}
In this article I explore relationships between love and politics by looking into Rosa Luxemburg's letters to her lover and comrade Leo Jogiches. My discussion is framed within Hannah Arendt's conceptualization of love as a manifestation of existence through the Augustinian journey of memory and as an existential force binding together the three faculties of the mind in her philosophical analysis: thinking, willing and judging. What I argue is that letters are crucial in enacting plurality and communication, and that Luxemburg's letters to her lover and comrade intensify rather than obscure the force of the political in opening up radical futures.
\end{abstract}

Keywords

Arendt, love, memory, narrative, politics, time

'No, I can't work any more. I can't stop thinking of you. I must write to you' (Luxemburg to Jogiches, 16 July 1897, in Ettinger, 1979: 22). This is the opening phrase of a love letter that starts agonistically: the urge to write to the beloved is posited as a dire need. The thought of the lover is juxtaposed to the imperative of work, but the latter, important as it is, seems to recede. After all, the letter writer is Rosa Luxemburg, a revolutionist, a Marxist, a leading figure of the socialist movement of her times, but also a woman in love. Luxemburg has been a controversial figure for many reasons and on many grounds. ${ }^{1}$ But for many of us who came of age in the wake of the European social movements of the 1970s, Luxemburg was mostly an inspiring figure, a living example of the 
strength of politics not just in changing the world but also, and perhaps more importantly, in revolutionizing the ways we lived and the ways we loved.

But given its multifarious meanings, configurations and expressions, how can love be conceptualized in relation to politics? ${ }^{2}$ This is the question that I want to explore in this article by reading Luxemburg's letters to her lover and comrade Leo Jogiches within the framework of Hannah Arendt's (1996) thesis on love. The article unfolds in four parts: first I chart lines of the Luxemburg/Arendt encounter and contextualize Luxemburg's letters and her relationship with Jogiches within the socio-political and cultural milieu of her era; in the second section I explicate and discuss the concept of love in Arendt's work as a manifestation of existence through the Augustinian journey of memory; third, I explore themes emerging from an analysis of Luxemburg's letters within an Arendtian framework, particularly focusing on the crucial role of epistolary narratives in enacting plurality and communication; finally, I revisit my initial proposition of making connections between love, memory and politics. What I suggest is that Luxemburg's letters bring the abstract question of the relationship between politics and love to life. Moreover, they create a particularly interesting epistolary archive, wherein a cluster of Arendtian ideas and propositions around the political and the human condition can be fleshed out and rethought in the light of her reconfiguration of the Augustinian notion of love. There is a need, I think, for more work in this area of Arendtian scholarship, given that the publication of her doctoral dissertation in English (Arendt, 1996) has opened up new and contested grounds for her overall work to be contextualized and reconsidered.

Read through Arendtian lenses, Luxemburg's letters throw new light on a grey area: intense interactions between love as force, and the political as a space of communication and action. Their reading actually exposes some of the tensions in Arendt's political thought, emerging, as Benhabib (1994: 111) has aptly pointed out, between 'two formative forces of her spiritual-political identity, German Existenzphilosophie of the late 1920s and her political experiences as a Jewish German intellectual'. As a new comprehensive collection of Luxemburg's letters has only recently been published (Adler et al., 2011), their rereading can offer new insights into Luxemburg's and indeed Arendt's agonistic politics. While reviewing this volume, and anticipating the publication of the 14 volumes of Luxemburg's corpus in English, Rose (2011:5) has suggested that 'the moment has clearly come for a return to Rosa Luxemburg'. But what does it mean to return, particularly when there are no clear paths or grounds to do so? Given the layers of distortion that have accumulated around her life and work, a return to Luxemburg should be taken as a genealogical descent (Foucault, 1986), a backwards move revealing 
numberless beginnings, discontinuities and ruptures, as well as surprising continuities.

As a matter of fact, Arendt was pivotal in returning to Luxemburg by choosing her as a woman whose life, in the form of a story, illuminated 'dark times' more effectively than theories and concepts could have done (Arendt, 1968: ix). As Kristeva (2001: 41) has noted, in reflecting upon and theorizing the narrated life, Arendt 'gave new life to the praxis of narrative, [forging] together the destinies of life, the narrative and politics'. But what were 'the dark times' that Luxemburg's life was illuminating? In writing the essay on Luxemburg, initially as a review (Arendt, 1966) of Nettl's (1966) biography, Arendt was endorsing the author's insightful decision to write the life story of 'the most controversial and least understood figure in the German Left movement' (Arendt, 1968: 34). It was therefore dark times in the history of European socialism, linked to the consequent rise of totalitarian regimes that Luxemburg's life was illuminating for Arendt. Indeed her essay is a thoughtful political analysis not only of the European political scene in the first decades of the 20th century, but also a critical genealogy of the European Left. Arendt was 'returning to Luxemburg' in the wake of the ruins of the European Left, but it is the political effects of these ruins that we still experience and seek to understand.

Rose's (2011) celebration of the much anticipated publication of Luxemburg's corpus in English bitterly reminds us that it was Lenin in 1922 who first asked for a complete edition of her work, soon after Levi had published her essay on the Russian revolution. ${ }^{3}$ There is a gap of almost a century since Luxemburg's murder, during which Lenin's successors tried hard, albeit unsuccessfully, to erase Luxemburg from the map of socialist thought. And yet, Luxemburg keeps returning every time there is a flicker of hope, a 'New Left', Arendt has noted (1968: 37), fascinated by Luxemburg's ideas around political action and the revolution, themes that were at the heart of her own interests and writings. ${ }^{4}$ It was through her involvement in the 1905 Russian revolution and her work with the revolutionary workers' councils that Luxemburg learnt that 'good organization does not precede action, but is the product of it' and that 'the organization of revolutionary action can and must be learnt in revolution itself' (Nettl, cited in Arendt, 1968: 52). Here also lies the source of her disagreement with Lenin and her criticism of his tactics in the 1918 revolution: 'she did not believe in a victory in which the people at large had no part and no voice' (Nettl, cited in Arendt, 1968: 53) and in a most clairvoyant way she 'was far more afraid of a deformed revolution than an unsuccessful one' (Nettl, cited in Arendt, 1968: 53).

Given Luxemburg's crucial influence on how we understand and make sense of politics and the revolution, it is no wonder then that Rose frames the return to Luxemburg in the wake of 'the Arab spring': 'We live in revolutionary times', she writes, and 'I cannot imagine now what it 
would have been like to be thinking about Rosa Luxemburg if the revolutions in Tunisia, Egypt and Libya had not taken place' (Rose, 2011: 5). Whether we agree or not with Rose's celebration of 'revolutionary times', the need for a return to Luxemburg certainly emerges as an Arendtian way of understanding - an attempt to 'think what we are doing' (Arendt, 1998: 5) within turbulent times - but it is also triggered by the publication of her letters, an event to which Rose's essay responds in the first place.

Arendt was indeed a fervent admirer of the poetry and lyricism of Luxemburg's letters. It was the event of the publication of 'two small volumes of her letters' (Arendt, 1968: 36), she writes, that brought a radical shift in the 'propaganda image of bloodthirsty Red Rosa' (Arendt, 1968: 36), although they also gave rise to a similarly problematic discourse, 'the image of the bird watcher and lover of flowers, a woman whose guards said good-by to her with tears in their eyes when she left prison' (Arendt, 1968: 36-7). Taking Luxemburg's letters as significant aspects of her legacy, what Arendt pithily identifies here is the need to excavate and deconstruct different layers of distortion around Luxemburg, so that her life can throw light on what it means to live passionately in revolutionary times. As Rose (2011:9) has forcefully put it: 'For Luxemburg, passion - like politics - was a question of freedom.'

Perhaps because freedom was at the heart of Arendt's life-long interests and work, she did develop passionate and visceral connections with Luxemburg. As Young-Bruehl (1982: 124) notes, Arendt was 11 years old 'when her mother took her to the Kö nigsberg demonstrations in support of the Spartacists'. ${ }^{5}$ What she did not know at the time was that her future husband Heinrich Blü cher - 20 years old at the time was among the young Spartacists marching against the First World War in Berlin (Young-Bruehl, 1982: 125). Arendt had thus heard a lot of anecdotal stories about Luxemburg, not only through the social democratic circles that her mother was involved in (Arendt, 1968: 37), but also later in life from Blü cher himself, who had read and admired Luxemburg's political writings. It is not surprising then that in reviewing Nettl's book Arendt (1968: 33) celebrates well-researched biographies as an 'admirable genre

of historiography', but also offers her own reading of Luxemburg's life and her relationship with Jogiches.

In criticizing Nettl's biographical account as having missed the fact that Luxemburg was 'so self-consciously a woman [and therefore] an outsider' (Arendt, 1968: 44), Arendt was also writing about her own experience of being a woman, but also 'an outsider', a European Jewish intellectual, as well as a refugee and later a migrant and a stateless person for more than 20 years. When choosing Rahel Varnhagen as the subject of her secondary doctoral thesis ${ }^{6}$ or when writing about Luxemburg, Arendt was drawing on the life stories of two women to problematize the condition of Jewish identity on two levels: 'the 
self-deception of assimilated Jews [...] that they were just as German as the Germans, just as French as the French [and] the self-deception of the intellectual Jews, that they had no "fatherland", for their fatherland actually was Europe' (Arendt, 1968: 42). While Varnhagen was for Arendt an exemplary case of the first misconception, Luxemburg was under the spell of the second, hence her 'utopian internationalism' (Arendt, 1968: 43) as well as the consequent 'inability to gauge correctly the enormous force of nationalist feeling in a decaying body-politic' (Arendt, 1968: 43).

Her criticism notwithstanding, Arendt had direct experiences of both levels of 'self-deception' and had tried to understand them through her analysis of the condition of 'the outsider' or 'the pariah' in her secondary thesis, as well as in a number of essays (see Arendt, 1978). As Benhabib (1994: 90) has noted, in writing Varnhagen's life, Arendt was tracing an existential transition, 'a move away from the psychology of the parvenu to that of the pariah'. In discussing Arendt's figure of the 'conscious pariah' (Arendt, 1978: 76), as inhabiting 'a privileged site from which one can secure the distance necessary for independent critique, action and judgement', Honig (1992: 231) has referred to Luxemburg as a 'conscious pariah' par excellence for Arendt.

Luxemburg's condition as 'a conscious pariah' in Arendt's analysis is closely intertwined with her relationship to Jogiches and is contextualized within the ethics, practices and politics of the 'Polish-Jewish "peergroup" [which] consisted of assimilated Jews from middle-class families, whose cultural background was German, their political formation Russian and their moral standards in both private and public life their own' (Arendt, 1978: 40). Following Nettl's lead in having identified the importance of this group, Arendt highlights its role in forging relational ties among its members that were drawing on common 'moral taste' (Arendt, 1978: 40), disregarding differences of political opinions, social, ethnic and even religious positions, 'in a world that was not out of joint' (Arendt, 1978: 41). But in rewriting Jogiches' role in Luxemburg's life, within the condition of 'the conscious pariah' and the socio-political context of the Polish-Jewish peer group, Arendt was also pointing to the need to perceive love as a passionate force of life, entangled within the web of human relations, which are always contingent and unpredictable:

Their deadly serious quarrel, caused by Jogiches' brief affair with another woman and endlessly complicated by Rosa's furious reaction, was typical of their time and milieu, as was the aftermath, his jealousy and her refusal for years to forgive him. This generation still believed firmly that love strikes only once, and its carelessness with marriage certificates should not be mistaken for any belief in free love. (Arendt, 1968: 45) 
As Young-Bruehl (1982: 239) has commented, it was her mother's generation that Arendt had in mind when writing about Luxemburg, but her essay is also coloured by her own intellectual and emotional relationships. ${ }^{7}$ It has to be noted, however, that the issues around faithfulness and jealousy that Arendt discusses above, have to be placed outside the constraints of bourgeois morality and conventions. Such questions need to be reframed within the psychosocial context of a revolutionary woman like Luxemburg or a Weimar Berliner like Arendt, who were interested not in 'loyal love' but in 'loyalty to love' (Young-Bruehl, 1982: 39).

It is therefore alternative loyalties to love and to the revolution that Luxemburg's letters express: in an Arendtian mode they disclose the uniqueness of 'who' Luxemburg is at the same time that they allow her to emerge in the web of human relations of which she is part. Luxemburg's letters thus become signs of uniqueness as well as traces of plurality, an essential condition of all political life in Arendt's thought (Arendt, 1998: 7). Through the narrative force of her letters, Luxemburg appears to the world as a woman whose passion and love for the world is inextricably interwoven with her political activities. As Rose (2011: 8) has insightfully put it, her correspondence should not be read 'as the sole repository of intimacy, but because it shows the ceaseless traffic between the personal and political'. In thus tracing the narrative force of Luxemburg's letters, it is on their personal/political entanglements that I will now focus, by returning to the epistolary extract, whose opening phrase was cited at the beginning of this article.

No, I can't work any more. I can't stop thinking of you. I must write to you. Beloved, dearest, you're not with me, yet my whole being is filled with you. It might seem irrational to you, even absurd, that I am writing this letter - we live only ten steps apart and meet three times a day - and anyway, I'm only your wife - why then the romanticism, writing in the middle of the night to my own husband? Oh, my golden heart let the whole world think me ridiculous, but not you. Read this letter seriously, with feeling, the same way you used to read my letters back in Geneva when I wasn't your wife yet. I'm writing with the same love as then; my whole soul goes out to you as probably you are smiling - 'after all, nowadays I cry for no reason at all!' (in Ettinger, 1979: 22)

Written from Switzerland on 16 July 1897, the letter above carries signs of tormented subjects within a turbulent era and starts with a disclaimer of its necessity or rationality. In interrupting what is important in her life, quite simply her political work, the author seeks to understand why she feels the urge to write to the beloved, who is not even absent, neither can he stand as a 'romantic' figure since he has become 'a 
husband'. It has to be noted here that Luxemburg and Jogiches never got married: the 'husband' and 'wife' positions are taken up in the epistolary discourse as a mode of denoting a long life partnership in love and politics, some events and trails of which I will now trace.

Luxemburg was 20 years old when she met Jogiches in Zurich in 1890 and he was three years older than her. They had fled their birth countries and were heavily involved in socialist politics. There were strong links but also significant differences between them. Apart from being young, Jewish, exiled from their countries and working in the same political circles, ${ }^{8}$ they were also both studying at the University of Zurich between 1890 and 1897. Luxemburg published her doctoral thesis, The Industrial Development of Poland, in 1898 (Luxemburg, 1977), but Jogiches never completed his own, despite Luxemburg's fervent endeavours to persuade him to do so. As she was writing from Berlin on 26 January 1900:

it makes me happy that you applied yourself with such passion to your paper, or rather to your doctorate. Working on it you have realized how well you can write (both in general and in German)... the doctorate will encourage you to try your hand at other kinds of work. (in Ettinger, 1979: 106)

On top of being a tireless political activist, Luxemburg was an inspiring theorist and an eloquent writer; but she would always send her speeches, essays and books to Jogiches: 'you don't know that everything I do is with you in mind. Always when I write an article, my first thought is you'll be thrilled by it' (in Ettinger, 1979: 71), she wrote on 6 March 1899 from Berlin. It has to be noted here of course that Luxemburg would also revolt against Jogiches' paternalistic attitude: 'You seem to be called upon to preach to me and to play the role of my mentor always, no matter what. Your current advice and criticism of my "activities" go far beyond a close friend's comment - it's just systematic moralizing' (in Ettinger, 1979: 89), she was poignantly writing from Berlin on 13 January 1900.

Jogiches was not just a critical reader but also an excellent political organizer; coming from a wealthy family he was also a constant source of funding both for 'the cause' and the relationship. ${ }^{9}$ Although they stayed together for 15 years, Luxemburg and Jogiches only spent short times living together and even when they did, they never really cohabited, keeping different, albeit neighbouring apartments, where they could avoid social criticism, but also work in peace. ${ }^{10}$ In this light, their letters, like all letters, were bridges between presence and absence, filling the gaps of a long-distance relationship, but also opening up channels of communication that sustained their love and their political action in concert. 'During the Schippel campaign your letters stimulated my thinking day by day', Luxemburg was writing from Berlin on 6 March 1899 
(in Ettinger, 1979: 72). But since politics and love are intertwined in their lived and epistolary relationship, the strains and frustration of not living together also leave their signs in the text of the same letter:

I felt happiest about the part of your letter in which you wrote that we are both still young and able to arrange our personal life. Oh, Dyodyu, my golden one, if only you keep your promise! .. . Our own small apartment, our own nice furniture, our own library; quiet and regular work, walks together, an opera from time to time, a small, very small, circle of friends who can sometimes be invited for dinner; every year a summer vacation in the country, one month with absolutely no work!... And perhaps even a little, a very little baby? Will this never be allowed? Never? (in Ettinger, 1979: 73-4)

There is a range of very interesting themes in the above letter, which I discuss in the third section of the article. What I want to highlight here is the forceful way that the epistolary extract above portrays a relationship bursting with tensions till its very end. But although Luxemburg and Jogiches broke up in 1907 their political relationship continued till the end of their lives. As already noted, in 1914 they established the Spartacus League, wrote articles and organized activities against the war. While Luxemburg was in prison, between 1915 and 1918, Jogiches looked after her 'and was constantly at her side' (Ettinger, 1982: 191). After the crash of the Spartacist Rising in Berlin and Luxemburg's murder in January 1919, Jogiches ignored warnings and stayed on, determined to reveal the crime of the Freicorps forces; he was murdered three months later, in March 1919. Their murder 'under the eyes and probably with the connivance of the Socialist regime then in power $[\ldots]$ by a paramilitary organization from which Hitler's storm troopers were soon to recruit their most promising killers' (Arendt, 1968: 35), as well as the eradication of Luxemburg's legacy by the Stalinist regime, marks one of the darkest moments in the history of the European Left, whose effects we still need to unravel and understand. In reading Luxemburg's letters to Jogiches, what we also need to imagine is their addressee, whose letters have not been preserved. Jogiches is of course the absent presence par excellence of Luxemburg's epistolary archive. How can one deal with the presence of the absent? There is a long philosophical inquiry around this Platonic theme that Ricoeur (2002) has considered and discussed in his influential theorization of memory and forgetting. As an external reader of these letters, Arendt has imagined Jogiches as 'a man of action and passion [who] knew how to do and how to suffer' (Arendt, 1968: 45). Rose has been less sympathetic: 'there is no gender cliche' that doesn't spring to mind when thinking about Leo Jogiches', she notes (Rose, 2011: 9). But although Rose makes a series of pertinent comments 
about the Luxemburg-Jogiches relationship, I cannot agree with her idea that Jogiches 'did not have an inner life' (Rose, 2011: 9); maybe he did not or could not find ways to express his feelings, but in any case we cannot know. From the epistemological perspective of epistolarity, letters are bridges between presence and absence, but they can never stand for or represent this absence. Since the focus of this article is not on the letter writers' 'inner lives', however, but on epistolary narratives as sites where love and politics become constitutive of each other, it is to the love-politics complex in Arendt's thought that I now turn.

\section{Love, Memory, Politics}

Love was at the heart of Arendt's theoretical interests: her doctoral thesis was on love in St Augustine, while, in writing Varnhagen's life, she particularly considered and discussed a Jewish woman's failure in 'matters of love' (Arendt, 2000). Love is further extensively discussed in the chapter on 'Action' of The Human Condition, particularly in relation to forgiveness. Love, 'one of the rarest occurrences in human lives, indeed possesses an unequalled power of self-revelation and an unequalled clarity of vision for the disclosure of who', writes Arendt (1998: 242). Love is thus configured as an existential force through which human beings appear to each other and to the world. But while facilitating the emergence of the uniqueness of the who, love is not concerned with the worldly character, 'the whatness' (Guaraldo, 2001: 27) of humans or things: 'by reason of its passion, [love] destroys the in-between which relates us to and separates us from others' (Arendt, 1998: 242). In short, love moves us away from the world, it is 'unworldly [...] not only apolitical but antipolitical, perhaps the most antipolitical of all antipolitical human forces' (Arendt, 1998: 242). Arendt's ambivalence in relation to the worldly character of love is thus stark in the above often-cited extracts of The Human Condition.

Removed from the political, love still remains important in the thought of a political theorist; it actually becomes a conditio sine qua non for life, shaping as Kristeva (2001: 31) has noted, the themes and directions of her later work. But how can love, as 'an antipolitical' force par excellence, affect the configuration of the political? Leaving aside personal grounds and ties in considering this riddle, I want to focus on love as an existential notion in Arendt's political thought. ${ }^{11}$ Here I draw on the argument that 'Arendt's categories and methods of theorizing are not fully intelligible unless read against the background of German existentialism' (Hinchman and Hinchman, 1994: 143), and particularly in relation to the influence of Jaspers, who was the supervisor of her doctoral thesis on love.

As Hinchman and Hinchman have further argued, Jaspers and Arendt attempted to bridge the gap between solitude and contemplation - so 
important for the 'authentic individual' of existentialist thought - and the worldliness of being, "whether through "communication" (Jaspers) or action in the political arena (Arendt)' (Hinchman and Hinchman, 1994: 143). In this context what I suggest is that love for Arendt is configured as a fort-da movement, through which the solitary individual flies away from the world, but then returns to it: an 'antipolitical' force that ultimately creates conditions of possibility for the constitution of the political. 'This rebellious return, this desire for rupture, renewal or renaissance', animates Arendt's writings on the world revolutions, Kristeva (2001: 34) has noted.

This configuration of love as a force of life and change is clearly not to be conflated with 'the inherent wordlessness of love' (Arendt, 1998: 52). As Arendt poignantly points out, 'love in distinction from friendship, is killed or rather extinguished, the moment it is displayed in public' (Arendt, 1998: 50), further adding that 'love can only become false and perverted when it is used for political purposes such as the change or salvation of the world' (Arendt, 1998: 52). Love is then a conditio sine qua non, but not the conditio per quam of the political: it can inspire revolutions but it cannot be used to justify or ground them. But since it is Augustine's notion of love that 'paves the way for a conceptualization of life as mobility, alterity and alteration' (Kristeva, 2001: 34), it is to Arendt's reconfiguration of the concept that I now turn.

Arendt's thesis 'Love and St Augustine' was defended in 1928, but while it was her first work to be published in German in 1929, it would become her last book-length manuscript to be published in English, in 1996, 21 years after her death. There is a gap of almost 70 years, which has greatly shaped the ways Arendtian notions have been read, operationalized, defended or disputed in political theory in general and its feminist strands in particular. ${ }^{12}$ My reading of Arendt's notion of love and the connections I draw with the political is thus situated in a field of scholarship that has followed the publication of her Augustinian thesis (see, among others, Hammer, 2000; Kampowski, 2009; Kristeva, 2001; Scott and Stark, 1996). It has to be noted, however, that this connection has become controversial; as Scott and Stark, the editors of this publication have noted, it "will continue to be so until the whole corpus of her work in Germany and America is evaluated and incorporated into the "'orthodox" rendering of Arendt's political thought' (Scott and Stark, 1996: viii)

Controversies notwithstanding, Arendt had started working on the thesis in 1960, with a publication in mind. As she was writing to Jaspers in 1966:

I am doing something odd on the side [...] I am rewriting my Augustine in English [...] It's strange - this work is so far in the 
past, on the one hand; but on the other, I can still recognize myself as it were; I know exactly what I wanted to say. (16 January 1966, in Arendt and Jaspers, 1993: 622)

The publication was never realized during her lifetime, but as a range of Arendtian scholars have argued, her thesis on Augustine remained central in the political writings of her maturity (see Scott and Stark, 1996).

Moreover, Augustine's thought is critical in how Arendt (1981) develops her section on 'the faculty of the Will and by implication to the problem of Freedom' in her posthumously published work The Life of the Mind, while the notion of love binds together the three faculties, namely Thinking, Willing and Judging. As Young-Bruehl has noted, we think since we love meaning and the search for truth, we will the pleasure that the continuation of things can offer and we judge within the disinterested love that the image of the beautiful - conceived as such within the Kantian notion of the 'enlarged mentality' - can offer us: 'an image of judging as a disinterested love... put together with the image of thinking as an eros for meaning and the image of willing, transformed into love, willing objects to continue being' (Young-Bruehl, 1982: 356, emphasis in the original). But this recurrence of love, as a concept binding the three faculties of the mind and as a force of life re-inserting us into the world, derives from its emergence as an effect of the Augustinian journey of memory, which I will discuss next.

In the quest of meaning for ourselves and our relationship to the world, the future cannot offer us any hope since it is directed to death, a certain point that defines the temporality of human existence, as influentially theorized by Heidegger (2003). In seeking fearlessness through love, ${ }^{13}$ Augustine's philosophy offers a different image of time that comes from the future and is directed towards the past, the moment of the beginning of the world, as well as our own beginning, namely our birth. This image of time can be humanly conceptualized through memory: 'Time exists only insofar as it can be measured, and the yardstick by which we measure it is space' (Arendt, 1996: 15). For Augustine then, memory is the space wherein we measure time, but what we can measure is only what remains fixed in memory from the 'no more' and what exists as expectation from the 'not yet'. As Arendt (1996: 15) eloquently puts it: 'It is only by calling past and future into the presence of remembrance and expectation that time exists at all.' Although timeless, the present does become 'the only valid tense', the Now 'is not time but outside time', Arendt (1996: 15) writes.

Love is crucial in the experience of the timeless Now: while for Augustine it is the love for God that can make humans forget their temporal existence in the contemplation of eternity, forgetfulness, 
Arendt (1996: 28) notes, 'is by no means only characteristic of the love of God'. In loving:

[man] not only forgets himself, but in a way [he] ceases to be [himself], that is this particular place in time and space. [He] loses the human mode of existence, which is mortality, without exchanging for the divine mode of existence, which is eternity. (Arendt, 1996:28)

But there is a problem in this self-forgetfulness and transcendence of human existence for Augustine: the Christian imperative to love thy neighbour. This is how the Augustinian journey of memory 'as a twostep process of isolation from and return to this world' (Hammer, 2000: 87) becomes so important for Arendt: 'the fact that the past is not forever lost and that remembrance can bring it back into the present is what gives memory its great power'. ${ }^{14}$ This Augustinian statement is what underpins and sustains Arendt's departure from Heidegger's orientation toward death, to the concept of natality that marks her own philosophy:

Since our expectations and desires are prompted by what we remember and guided by a previous knowledge, it is memory and not expectation (for instance the expectation of death as in Heidegger's approach) that gives unity and wholeness to human existence. (Arendt, 1996: 56)

Augustine's existential question par excellence, 'I have become a question to myself', ${ }^{15}$ initiates a memory journey in which 'the beginning and end of [his] life become exchangeable' (Arendt, 1996: 57). In remembering the past and its joys we also transform them into future possibilities, while human existence appears as what it is: an 'everlasting Becoming' (Arendt, 1996: 63), in a world that is both physical and human. It is in the realization of existence in the human world that the neighbourly love emerges, since the human world 'constitutes itself by habitation and love (diligere) [...] love for the world [...] rests on being of the world' (Arendt, 1996:66).

Indeed, amid the three configurations of love in Augustine's philosophy, 'love as craving (appetitus), love as a relation between man and God the Creator, and neighbourly love' (Young-Bruehl, 1982: 74), it is the latter that fascinates Arendt. Neighbourly love as an existential concept is also crucial in her philosophical thought as influenced by Jaspers. As Young-Bruehl has pithily remarked: 'Augustine's three types of love are also examined with existential concepts crucial to the three dimensions of philosophizing Jaspers had formulated... a world-oriented love (appetitus), an existential love (neighbourly love) and a transcendent love (love of the Creator)' (Young-Bruehl, 1982: 75). The significance of the 
neighbourly love in Arendt's political thought is linked to the way she reconfigured the temporal structure of human existence in her dissertation: worldly love is future oriented, transcendent love is directed towards the ultimate past, while it is only neighbourly love that exists in the present, absorbing, as it were, 'the other modes of temporal existence and the capacities they presuppose... hope and memory' (YoungBruehl, 1982: 76).

By illuminating the present, the timeless space between the 'no longer' and the 'not yet', Arendt highlights natality as the defining aspect of human temporality and is concerned with politics as an arena where new beginnings are always possible, as history has so forcefully shown: 'the essence of all, and in particular of political action, is to make a new beginning' (Arendt, 1994: 321). But these new beginnings are also closely interrelated with freedom as inherent in the human condition:

Man does not possess freedom so much as he, or better his coming into the world, is equated with the appearance of freedom in the universe [...] Because he is a beginning, man can begin; to be human and to be free are one and the same. (Arendt, 2006: 165-6)

Thus, while the final destination of Augustine's memory journey is God, Arendt's chosen destination is humanity, the remembrance of what binds us together, namely our birth in the world, 'for the sake of novitas' (Arendt, 1996: 55) and therefore freedom. Having retreated from the world in the quest for meaning, we thus follow an Augustinian journey of memory from the future into the past and, by reaching our birth as a common experience that binds us as humans, we reconcile ourselves with the world and through the experience of neighbourly love, 'as an expression of interdependence' (Arendt, 1996: 104), we reposition ourselves in-the-world-with-others. ${ }^{16}$ Love is then an existential concept in Arendt's political thought that binds together the two crucial components of her philosophy, uniqueness and plurality: 'existence can develop only in the shared life of human beings inhabiting a given world common to them all', she writes (Arendt, 1994: 186).

It was the image of 'a given world common to all' that Arendt was visualizing when she wrote Varnhagen's life; in doing this she was able to flesh out the existential concept of love by drawing on stories inscribed in diaries and letters. Narratives are indeed at the heart of how Arendt conceptualizes the human condition. Drawing on the Aristotelian notion of energeia, Arendt's thesis is that 'action as narration and narration as action are the only things that can partake in the most "specifically human"' aspects of life' (Kristeva, 2001: 41). As the only tangible traces of human existence, stories in Arendt's thought evade theoretical abstractions and contribute to the search of meaning by revealing multiple perspectives while remaining open and attentive to the unexpected, 
the unthought-of; they 'respect the contingency of action' (Guaraldo, 2001: 214) and express the unpredictability of the human condition. In doing so stories ultimately reconfigure the sphere of politics as an open plane of horizontal connections, wherein the revolution can once again be re-imagined.

In this light, epistolary narratives constitute a discursive site for memory journeys to be initiated and for love to emerge as a force of life that makes the isolated individual 'feel at home in the world' through remembering, communicating and ultimately acting. As Disch (1994: 172) has commented, 'feeling at home in the world' is a constant preoccupation in Arendt's political thought, since the crucial problem she identifies in The Human Condition is 'world alienation and not self-alienation as Marx thought' (Arendt, 1998: 254). For Arendt, then, our involvement in the web of human relations, and therefore in action, is the only way we can feel again 'at home in this world'. In this light, it is the force of the epistolary form in acting through narration that brings the discussion back to Luxemburg's letters. In doing this I now return to the last part of the birthday letter of 6 March 1899, already cited in the previous section.

\section{Dear Dyodyu: Epistolary Narratives of Love and Struggle}

... Dyodyu, if only you'd settle your citizenship, finish your doctorate, live with me openly in our own home. We will both work and our life will be perfect!! No couple on earth has the chance we have. With just a little goodwill we will be happy, we must. Weren't we happy when just the two of us lived and worked together for long stretches of time? Remember Weggis? Melida? Bougy? Blonay? Remember when we are alone in harmony, we can do without the whole world? ... Remember, last time in Weggis when I was writing 'Step by Step' (I always think with pride about that little masterpiece), I was sick writing in bed, all upset, and you were so gentle, so good, sweet [...] Or do you remember the afternoons at Melida, after lunch, when you sat on the porch, drinking black thick coffee, sweating in the scorching sun, and I trudged down to the garden with my 'Administrative Theory' notes. Or do you remember, how once a band of musicians came on a Sunday to the garden [...] and we went on foot to Maroggia and we came back on foot, and the moon was rising over San Salvadore, and we had just been talking about my going to Germany. We stopped, held each other on the road in the darkness and looked at the crescent moon over the mountains. Do you remember? I still smell the night's air. Or, do you remember how you used to come back from Lugano at 8:20 at 
night, with the groceries [...] Oh, you know, we have probably never had such magnificent dinners as those, on the little table in that bare room, the door to the porch open, the fragrance of the garden sweeping in, and you, with great finesse, scrambling eggs in a pan. And from afar in the darkness the train to Milan was flying over the bridge, thundering [...] Oh Dyodyu, Dyodyu! Hurry up, come here; we'll hide from the whole world; the two of us in two little rooms, we'll work alone, cook alone, and we'll have a good, such a good life! [...] Dyodyu dearest, I throw my arms around your neck and kiss you a thousand times. I want you. [...] I don't want to write about business today - tomorrow, after seeing Kautsky [...] I hug you and kiss you on the mouth and on my belovedest nose and absolutely want you to carry me in your arms.

$$
\text { Yours, Ró za a (in Ettinger, 1979: 73-5) }
$$

Among the many things that strike me in reading Luxemburg's poetic letter above is the recurrence of the 'do you remember?' question. Written on the day of her birthday, the narrative reiteration of the need to remember becomes particularly significant in the light of Arendt's existential concept of love and its link to memory, natality and politics as discussed in the previous section. It is by recalling past (and scarce) moments of living together with the beloved - who is also a comrade and a political mentor - that Luxemburg's amorous discourse unfolds. What is also important is that memories of the crescent moon, the train passing by in the darkness, simple dinners in the Italian countryside and worries about Kautsky's reception of her work, the ordinary and the extraordinary, are crammed together in the body of this letter.

In discussing the discourse of remembrance in amorous epistolary narratives, Kauffman (1986: 17) has noted that retrieving past moments of happiness in the text of the letter is an amorous epistolary practice that goes back to Ovid's Heroids. ${ }^{17}$ But while the Ovidean heroine writes to the beloved recalling past moments of happiness - since writing is the only act that can revert the position of 'the deserted woman' - there is a significant inflection in Luxemburg's epistolary practices: the memory of blissful moments goes hand in hand with the memory of political creation and action: the period when she was writing 'the little masterpiece' Step by Step or working with The Administrative Theory Notes. Luxemburg is not 'a deserted woman' - although sometimes she feels so as a result of Jogiches' indifference - but a political actor, who wants to change the world, not just on the macro level but also in the minutiae of everyday life. In this light she actively seeks and claims the pleasure and right of being happy: 'we will be happy, we must', she notes emphatically in the birthday letter above. 
But for Luxemburg the often controversial and ambiguous image of ' $\mathrm{a}$ happy life ${ }^{18}$ is interwoven in the web of political relations in a mutual codependence. A 'happy life' for Luxemburg is about loving, studying, writing, acting; as a revolutionary she wants them all and she wants them in the Now that she reflects upon and wills to revolutionize and radically change. In tracing signs of the author's expression of a forceful will, the external reader of these letters cannot but make connections with Arendt's configuration of love as an existential force that binds together thinking, willing and judging in Luxemburg's 'life of the mind'. Luxemburg's Now is Arendt's timeless present, a site of struggle, but also a region par excellence for thinking and remembering: 'The gap between past and future opens only in reflection [which] draws these absent "regions" into the mind's presence; from that perspective the activity of thinking can be understood as a fight against time itself' (Arendt, 1981: 206).

Luxemburg needs these regions 'to hide from the world' in the company of her lover, but this retreat is not 'antipolitical' in the way Arendt has discussed it in The Human Condition (Arendt, 1998: 242). This moving away from the world is only temporary, sheltering and nurturing the lovers and thus strengthening them for a return to the world, the political arena and the fight for the revolution. Far from being 'apolitical' or 'antipolitical', Luxemburg's retreat opens up spaces in the margins; indeed, many of her letters are written in border situations - be they the author's birthday, life in prison or critical political events. ${ }^{19}$ In Jaspers' existential philosophy, border situations create conditions of possibility for existential appearances: 'We become aware of Being by proceeding in thought from the "imagined world of the merely thinkable" to the border of reality, which as a pure object of thought or pure possibility can no longer be grasped' (Arendt, 1994: 184). What is crucial in Jaspers' thought for Arendt is the recognition that 'being as such is not knowable' (Arendt, 1994: 186). This acknowledgement creates 'an island of human freedom [...] marked by the border situations in which [man] experiences the limitations that directly determine the conditions of [his] freedom and provide the basis for his actions' (Arendt, 1994: 186).

In this context, border situations illuminate existence and can orientate actions: communication is thus conceived as the milieu par excellence wherein existence is manifested and therefore realized. Luxemburg's letters, I argue, carry traces of thought within border situations of existential appearance and thus open up possibilities of communication about politics, the revolution and the lovers' life, in a future that is radical and open. Indeed, the particulars of Luxemburg's and Jogiches' lives were continuously creating conditions of possibility for border situations to be enacted: they were two young Jewish exiles, heavily involved in revolutionary politics and in disagreement with the party line of the social democratic circles in Germany. But in writing to each other from the 
margins they were experiencing border situations within which a new image of the world was possible. In this light the unbearable heaviness of being separated from the beloved was not just a contingency of the amorous relationship: while visualizing a different world, Luxemburg was specifically situating her life within it. Her letters to Jogiches are thus creating tangible links between the particular and the universal. In reflecting upon the unhappiness of her own life, she was departing from the abstractness of political discourse and could thus conceptualize and configure a different politics of 'feeling at home in the world' (Disch, 1994: 172). Although accepting the fragmentation of the world, through her letters Luxemburg was attempting 'to accommodate the modern sense of alienation in the world and the modern desire to create, in a world that is no longer a home to us, a human world that could become our home' (Arendt, 1994: 186).

In doing this Luxemburg was continuously confronted with different ideas and perspectives: not just those of the social democratic circles she was refuting and in which she was acting in concert with Jogiches, but also with those of the beloved. Her letters to Jogiches stage a scene of an ongoing struggle of ideas and perspectives - not so much about politics but mostly about love-in-politics - that would remain open till the very end. As Arendt (1968: 45) has poignantly pointed out, it was not jealousy, as Nettl has argued, but war, imprisonment, the failure of the revolution and their murder that has made the Luxemburg-Jogiches relationship 'one of the great and tragic love stories of Socialism' (Nettl, cited in Arendt, 1968: 45).

Thus the ambivalence and openness that mark the discourses, thematic preoccupations and forms of epistolary narratives take up particularly political meanings in Luxemburg's letters to Jogiches. On the one hand they most forcefully express the potential of epistolary narratives in enabling human communication, while revealing its failures and limitations; on the other hand they rigorously show that it is only in communication - with all its limitations and constraints - that a project of humanistic politics can ever be realized. In the light of Jaspers' philosophy, so influential for Arendt, Luxemburg's letters become important documents carrying traces of existential and political communication at work. What I further suggest is that these letters intensify the political dimension of Luxemburg's work rather than obscure it: it is in the interplay between existential appearances and political reflections that human beings become most profoundly aware of their freedom and their will to fight for it.

In this context, Luxemburg's letters expose some of the tensions and ambivalences in the conceptualization of love in Arendt's work as discussed in the second section of this article. ${ }^{20}$ More specifically, they show that the statement in The Human Condition that love is an 'antipolitical force' (Arendt, 1998: 242) can create misunderstandings if Arendt's 
notion of love is not read as an existential category or if it is isolated from Arendt's overall political thought as well as her posthumous work The Life of the Mind (Arendt, 1981). Herein lies the force of narratives in grounding abstractions, operationalizing concepts and reconnecting philosophical ideas to politics and life, which was after all what both Luxemburg and Arendt strived to do through their life and work. Moreover, the intense corporeal elements of Luxemburg's passionate love letters - 'I kiss you on the mouth and on my beloved nose' (6 March 1899, in Ettinger, 1979: 75) - point to the absence of the visceral in Arendt's consideration of love as a force of life and remind us of the need for feminist genealogies of Love as Eros to be written (Tamboukou, 2010: 146).

\section{To the Letter: Love in Politics, Politics in Love}

In exploring 'the content of the form' of narrative discourse in historical thought, White has influentially suggested that 'narrative, far from being merely a form of discourse that can be filled with different contents, real or imaginary as the case may be, already possesses a content prior to any given actualization of it in speech or writing' (White, 1987: xi). Following White's line of thought around the 'content of the form', what I have suggested in this article is that Luxemburg's letters to her lover and comrade Jogiches create an interesting archive wherein the epistolary form dramatizes and gives specificity to the relationship between politics and love.

Luxemburg's letters have been read as Arendtian stories: tangible traces of the contingency of action and the unpredictability of the human condition, constitutive of politics and of the discourse of History. In acting and speaking together, human beings expose themselves to each other, reveal the uniqueness of who they are and, through taking the risk of disclosure, they connect with others. In this light, narration creates conditions of possibility for uniqueness, plurality and communication to be enacted within the Arendtian configuration of the political. Love as an effect of the journey of memory and as a force of life is crucial here: through love we reconnect with the moment of our beginning, thus becoming existentially aware of freedom as an inherent possibility of the human condition, a principle 'created when man was created but not before' (Arendt, 1998: 177).

In opening up paths to the anamnesis of freedom, Luxemburg's love letters to Jogiches created conditions of possibility for existential border situations to be enacted and for their life and relationship to be re-imagined within the horizon of the revolution they were fighting for. For their external readers, the force of these passionate letters around love and politics illuminate 'dark times' in the history of the world and facilitate existential leaps into open and radical futures. 


\section{Acknowledgements}

I started writing this article while on a writing retreat week in Cairns, Australia, in July 2010, as part of a visiting fellowship grant by the Australian Academy of the Humanities for which I am deeply grateful. I want to thank the Victoria University and the Narrative Network Australia for hosting me in Melbourne, and particularly Marty Grace, Enza Gadolfo and Michele Grossman. I also want to thank the women who were part of this writing retreat: Elaine Martin, Jo Mesinga, Margaret Stebbing, Rosie Welch, and particularly Ruth Ballardie for organizing it.

\section{Notes}

1. Luxemburg's life has been the topic of two main biographies and several biographical sketches. See, among others, Nettl (1966) and Ettinger (1982).

2. Clearly there is a long line of philosophical approaches to love and a rich body of literature around it, but given the limitations and scope of this essay, I will focus on the Augustinian notion of love, or rather Arendt's reading of it.

3. This essay was written in 1918 without intention of publication. Lenin's response was that ' in spite of her mistakes ... [Luxemburg] was and is an eagle' (Arendt, 1968: 55).

4. Before her Luxemburg essay, Arendt had published The Human Condition in 1958 and On Revolution in 1963.

5. The Spartacus League was an underground political organisation founded by Luxemburg and Jogiches, among others, in 1914. See Nettl (1966), Ettinger (1982) and Bronner (1993).

6. The book was first published in 1957 but it was written much earlier while Arendt was still in Germany (first draft 1933) and later in Paris, where Benjamin actively encouraged her to complete it around 1938. See Arendt (2000: 5, 50).

7. Young-Bruehl (1982: 135) has suggested that in writing about Jogiches, Arendt was drawing Blü cher's pen portrait. In her biography, Ettinger (1982: 146-7) has looked into how Luxemburg struggled with Jogiches' affair. Ettinger (1995) was also the first to write about the Arendt-Heidegger love affair, mostly drawing on their letters.

8. In 1893, Luxemburg and Jogiches founded together the first influential Polish Marxist workers' party, the Social Democracy of the Kingdom of Poland (SDKP), which was reorganized in 1900 as the Social Democracy of the Kingdom of Poland and Lithuania (SDKPiL). See Ettinger (1979: 2-3, 195-6).

9. For more biographical details about Jogiches, see Ettinger (1982).

10. Social criticism was an issue even for the revolutionary circles of Zurich and Berlin, and Luxemburg often expresses her concern in her letters.

11. By bracketing Arendt's relationship with Heidegger and Blü cher, I do not want to say that they were not influential in her theoretical conceptualiza- tion of love, but that their discussion goes well beyond the limits of this paper. For interesting insights in Arendt's worldly love relationships, see, among others, Kristeva (2001) and Young-Bruehl (1982). See also the Arendt-Blü cher (1996) and the Arendt-Heidegger (2004) correspondence. 
12. See Honig (1995) for an excellent collection of the debates around Arendt's work in political theory and feminist scholarship.

13. In explicating Augustine's notions of love as craving, Arendt (1996: 11-12) writes: 'This fearlessness is what love seeks. Love as craving (appetitus) is determined by its goal, and this goal is freedom from fear (metu carere).'

14. Augustine's Confessions, X, 17, 26; X, 8, 14 (in Arendt, 1996: 56).

15. Augustine's Confessions, X, 33, 50 (in Arendt, 1996: 57).

16. See Hammer (2000) for an excellent discussion of the Augustinian journey of memory and the way it shapes Arendt's political thought.

17. In Ovid's Heroids, 15 heroines write verse letters to the beloved who has deserted them.

18. See Ahmed (2010) for a feminist critique of happiness.

19. Given the limitations of this paper, I cannot discuss in detail more letters where border situations emerge. Rather than using phrases and extracts from a variety of letters, I decided to present and discuss in detail the 6 March 1899 birthday letter as an encompassing epistolary appearance of important themes emerging in Luxemburg's correspondence.

20. I am grateful to the anonymous reviewer who brought this insight in the horizon of this essay.

\section{References}

Adler, G., Hudis, P. and Laschitza, A. (eds) (2011) The Letters of Rosa Luxemburg, trans. Shriver G. London: Verso.

Ahmed, S. (2010) The Promise of Happiness. Durham, NC: Duke University Press.

Arendt, H. (1966) 'A heroine of revolution', New York Review of Books, 6 October.

Arendt, H. (1968) Men in Dark Times. New York: Harvest Books.

Arendt, H. (1978) The Jew as Pariah, ed. Feldman R.H. New York: Grove Press.

Arendt, H. (1981) The Life of the Mind, ed. McCarthy M. New York: Harcourt.

Arendt, H. (1990) On Revolution. London: Penguin. (First published 1963.)

Arendt, H. (1994) Essays in Understanding 1930-1954: Formation, Exile and Totalitarianism, ed. Kohn J. New York: Schocken Books.

Arendt, H. (1996) Love and St Augustine, ed. Vecchiarelli Scott J. and Stark J.C. Chicago: University of Chicago Press.

Arendt, H. (1998) The Human Condition. Chicago: University of Chicago Press. (First published 1958.)

Arendt, H. (2000) Rahel Varnhagen: The Life of a Jewess, ed. Weissberg L., trans. Winston R. and Winston C. Baltimore, MD: Johns Hopkins University Press. (First published 1957.)

Arendt, H. (2006) Between Past and Future: Eight Exercises in Political Thought. London: Penguin Books. (First published 1961.)

Arendt, H. and Blü cher, H. (1996) Between Four Walls: The Correspondence between Hannah Arendt and Heinrich Blücher, 1936-1968, ed. Kö hler L., trans. Constantine P. New York: Harcourt.

Arendt, H. and Heidegger, M. (2004) Letters, 1925-1976, ed. Ludz U., trans. Shields A. New York: Harcourt Brace. 
Arendt, H. and Jaspers, K. (1993) Correspondence, 1926-1969, ed. Kö hler L. and Saner H., trans. Kimber R. and Kimber R. New York: Harcourt.

Benhabib, S. (1994) 'Hannah Arendt and the redemptive power of narrative'. In: Hinchman L. and Hinchman S. (eds) Hannah Arendt: Critical Essays. New York: State University of New York Press, pp. 111-141.

Bronner S.E. (ed.) (1993) The Letters of Rosa Luxemburg, trans. Bronner S.E. Atlantic Highlands, NJ: Humanities Press.

Disch, L.J. (1994) Hannah Arendt and the Limits of Philosophy. Ithaca, NY: Cornell University Press.

Ettinger, E. (1979) Comrade and Lover: Rosa Luxemburg's Letters to Leo Jogiches. Cambridge, MA: MIT Press.

Ettinger, E. (1982) Rosa Luxemburg: A Life. London: Pandora.

Ettinger, E. (1995) Hannah Arendt, Martin Heidegger. New Haven, CT: Yale University Press.

Foucault, M. (1986) 'Nietzsche, genealogy, history'. In: Rabinow P. (ed.) The Foucault Reader. Harmondsworth: Penguin, pp. 76-100.

Guaraldo, O. (2001) Storylines: Politics, History and Narrative from an Arendtian Perspective. Jyvä skulä : Sophi.

Hammer, D. (2000) 'Freedom and fatefulness: Augustine, Arendt and the journey of memory', Theory, Culture \& Society 17(2): 83-104.

Heidegger, M. (2003) Being and Time, trans. Macquarrie J. and Robinson E. Oxford: Blackwell. (First published 1926.)

Hinchman, L. and Hinchman, S. (1994) 'Existentialism politicized: Arendt's debt to Jaspers'. In: Hinchman L. and Hinchman S. (eds) Hannah Arendt: Critical Essays. New York: State University of New York Press, pp. 143-178.

Honig, B. (1992) 'Toward an agonistic feminism: Hannah Arendt and the politics of identity'. In: Butler J. and Scott J.W. (eds) Feminists Theorize the Political. New York: Routledge, pp. 215-235.

Honig B. (ed.) (1995) Feminist Interpretations of Hannah Arendt. University Park, PA: Pennsylvania State University Press.

Kampowski, S. (2009) Arendt, Augustine, and the New Beginning: The Action Theory and Moral Thought of Hannah Arendt in the Light of Her Dissertation on St. Augustine. Grand Rapids, MI: William B. Eerdmans Publishing.

Kauffman, L.S. (1986) Discourses of Desire: Gender, Genre and Epistolary Fictions. Ithaca, NY: Cornell University Press.

Kristeva, J. (2001) Hannah Arendt, trans. Guberman R. New York: Columbia University Press.

Luxemburg, R. (1977) The Industrial Development of Poland. New York: Campaigner Publications. (First published 1898.)

Nettl, J.P. (1966) Rosa Luxemburg, 2 Vols. New York: Oxford University Press.

Ricoeur, P. (2002) Memory, History, Forgetting, trans. Blamey K. and Pellauer D. Chicago: University of Chicago Press.

Rose, J. (2011) 'What more could we want of ourselves!' London Review of Books 33(12): 5-12.

Scott, J.V. and Stark, J.C. (1996) 'Preface: rediscovering love and St Augustine'. In: Arendt H., Love and St Augustine, ed. Scott J.V. and Stark J.C. Chicago: University of Chicago Press, pp. vii-xvii.

Tamboukou, M. (2010) Nomadic Narratives, Visual Forces: Gwen John's Letters and Paintings. New York: Peter Lang. 
White, H. (1987) The Content of the Form: Narrative Discourse and Historical Representation. Baltimore, MD: Johns Hopkins University Press.

Young-Bruehl, E. (1982) Hannah Arendt: For Love of the World. New Haven, CT: Yale University Press.

Maria Tamboukou is Professor of Feminist Studies and Co-director of the Centre of Narrative Research at the University of East London, UK. Her research interests and publications are in auto/biographical narratives within Arendtian, Foucauldian and Deleuzian frameworks. Recent publications include the monograph In the Fold between Power and Desire: Women Artists' Narratives (2010) and the co-edited collections Doing Narrative Research (2008) and Beyond Narrative Coherence (2010). 